\title{
Review of O.A. Leontovich, M.A. Gulyaeva, O.V. Lunyova, M.S. Sokolova. 2019. Positive communication. Moscow: Gnosis. 295 p. ISBN 978-5-94244-072-5
}

\author{
Vladimir I. KARASIK \\ Pushkin State Russian Language Institute \\ Moscow, Russia
}

For citation:

Karasik V.I. Review of O.A. Leontovich, M.A. Gulyaeva, O.V. Lunyova, M.S. Sokolova. 2019. Positive communication. Moscow: Gnosis. 295 p. ISBN 978-5-94244-072-5. Russian Journal of Linguistics 24 (4). 1055-1061. DOI: 10.22363/2687-0088-2020-24-4-1055-1061

Рецензия

\section{Рецензия на книгу: \\ Леонтович О.А., Гуляева М.А., Лунёва О.В., Соколова М.С. Позитивная коммуникация. - Москва: Гнозис, 2019. - 295 с. ISBN 978-5-94244-072-5 \\ В.И. КАРАСИК \\ Государственный институт русского языка имени А.С. Пушкина Москва, Россия}

\section{Для цитирования:}

Карасик В.И. Рецензия на книгу: О.А. Леонтович, М.А. Гуляева, О.В. Лунёва, М.С. Соколова; под общ. ред. проф. О.А. Леонтович. - Москва: Гнозис, 2019. - 295 с. ISBN 978-5-94244-072-5. Russian Journal of Linguistics. 2020. Vol. 24. № 4. P. 1055-1061. DOI: $10.22363 / 2687-0088-2020-24-4-1055-1061$

Изучение коммуникации как предмета лингвистического анализа привлекает к себе множество современных исследователей. Хорошо изучены структурно-системные характеристики общения, детально описаны психолингвистические и прагмалингвистические его аспекты, существенный вклад в развитие теории коммуникации внесли специалисты, рассматривающие различные характеристики дискурса. В меньшей мере освещены особенности коммуникации с позиций участвующих в ней личностей. Рецензируемая коллективная монография, вышедшая под редакцией известного отечественного специалиста в области теории коммуникации профессора Ольги Аркадьевны 
Леонтович, посвящена личностному измерению общения и в этом плане представляет собой обоснование и развитие теории коммуникации в новом направлении - на стыке с теорией языковой личности.

Книга состоит из шести глав, посвященных соответственно понятию позитивной коммуникации, позитивной личности, коммуникативной инициативе, вовлеченности в коммуникацию, адаптации к собеседнику и социальной поддержке. Рецензируемое исследование в полной мере соответствует жанру монографии: это глубокий анализ четко очерченной проблемы, разработка теоретической модели ее изучения и тщательно выполненное описание фактического материала.

В предисловии к монографии ее научный редактор объясняет актуальность изучения позитивной коммуникации тем, что этот вид общения исключительно важен для здорового состояния общества, он должен быть противопоставлен нарастающей речевой агрессии в разных типах дискурса, и при этом он не разработан в теоретическом отношении. Сказанное свидетельствует о несомненной своевременности выхода в свет этой книги.

О.А. Леонтович следующим образом определяет ключевое понятие исследования, характеризуя позитивную коммуникацию как «благоприятную, эффективную, конструктивную, выражающую положительную интенцию, оптимизм, психологическую поддержку собеседника, настрой на положительный исход общения, прогресс и развитие» (с. 14). Автор доказывает, что основными признаками такого общения являются конструктивность, окрашенность положительными эмоциями и эффективность, в качестве факультативных признаков названы информативность и ассертивность, под которой понимается «напористость, не переходящая в агрессивность». Справедливо отмечено, что ассертивность имеет несомненную этнокультурную специфику: если в США успешное продвижение себя считается нормой поведения и получает у многих одобрение, то в других странах, в частности в России, такое поведение обычно оценивается критически.

Модель изучения позитивной коммуникации построена как пятичленное образование, включающее коммуникативную инициативу, вовлеченность в коммуникацию, адаптацию к собеседнику, социальную поддержку и конгруэнтность. Эти понятия еще недостаточно освоены в филологии. Коммуникативная инициатива объясняется как наличие положительной интенции у индивида, вовлеченность в общение - как эмпатическое сопереживание, коммуникативная адаптация - как приспособление к адресату, обусловленное возрастом, гендером, статусными и культурными признаками, социальная поддержка - как демонстрация готовности помочь партнеру по общению, конгруэнтность - как соответствие внутреннего «Я» индивида его внешним проявлениям, т.е. как искренность и открытость. Заслуживает внимания предложенная в работе система антиномий, позволяющих осмыслить сущность позитивной коммуникации: «позитив - негатив (= не позитив), аттракция - дезаттракция, инициативность - пассивность (безынициативность), 
вовлеченность в коммуникацию - отчужденность (невовлеченность), эгоцентризм - альтероцентризм, социальная поддержка - социальная индифферентность (отсутствие социальной поддержки), конструктивная - деструктивная коммуникация» (с. 22-23). Эти антиномии объясняют и уточняют ключевые признаки анализируемого понятия.

В книге детально охарактеризовано понятие «позитивная личность». Опросив 200 информантов, авторы определили признаки такой личности в современном российском языковом сознании (оптимизм, положительное отношение к окружающим, активность, лидерские качества, неординарность, гармония с собой, интеллект и др.) и установили типичных носителей таких качеств, среди которых было названо 168 известных людей (лидерами оказались известные представители медийно-развлекательной индустрии - Иван Ургант, Владимир Познер, Константин Хабенский). Отвечая на вопросы в анкете, информанты выделили следующие характеристики положительного отношения к окружающим (в скобках указано количество упоминаний): доброжелательность (16), дружелюбие (11), доброта (11), умение общаться с людьми (5), неконфликтность (5), эмпатия (4), добродушие (4), готовность прийти на помощь (4), отзывчивость (3), забота о других (2), приветливость (2), умение быть благодарным (2), умение радоваться за других (2), сочувствие (2), уважение к окружающим (2), тактичность (2), незлобивость (2), умение не обременять других своими заботами (2), великодушие (1), добросердечность (1), сострадание (1), сопереживание (1), надежность (1), терпимость (1), воспитанность (1), вежливость (1), дипломатичность (1), сдержанность в высказываниях (1), интеллигентность (1), умение быть снисходительным к чужим слабостям (1), умение прощать (1) (с. 36-37). Эти данные можно рассматривать как важные признаки русской ценностной картины миры. Тот факт, что в ряду образцовых позитивных личностей оказались популярные журналисты и шоумены, свидетельствует о значимости медийной индустрии в наше время и о специфике коммуникативного стиля нашей эпохи.

Важнейшей характеристикой позитивной личности, как показано в исследовании, является коммуникативная аттракция - привлекательность партнера по общению в биологическом, социальном, психологическом и культурном аспектах. Читатели несомненно обратят внимание на установленные в исследовании характеристики позитивной личности в аспекте межкультурного общения. Заслуживают внимания выделенные в книге специфические коммуникативные стратегии самопрезентации, к числу которых О.А. Леонтович относит самопозиционирование (принижение себя в восточных культурах и отсутствие такого самопринижения в американском коммуникативном поведении), ассертивность (во многих культурах этот тип поведения признается нескромным), сохранение лица (в коллективистских культурах участники общения стремятся прежде всего сохранить лицо партнера, в индивидуалистских - собственное лицо), роль юмора (наличие иронии и самоиронии, 
степень прямолинейности и т.д.), использование молчания (допустимый лимит молчания в общении существенно различается в «теплых и холодных» культурах). Эти наблюдения весьма интересны, но я бы в этой связи подчеркнул значимость не только этнокультурной, но и социокультурной специфики в понимании самопрезентации: поведение представителей среднего класса и социальных низов имеет существенные различия. Кроме того, самопрезентация в общении весьма специфична применительно к разным типам дискурса: то, что считается нормой в контактном личностном общении, весьма часто нарушается в дистантных сетевых интеракциях.

Весьма интересны разделы книги, детально характеризующие компонентный состав позитивной коммуникации.

О.В. Лунёва раскрывает суть феномена «коммуникативная инициатива», сравнивает его с явлениями коммуникативной активности и лидерства, объясняет причины взятия инициативы, устанавливает константные и переменные составляющие этого понятия, выделяет его базовые функции. Автор предлагает рассматривать коммуникативную инициативу в следующих аспектах: 1) уточнение характеристик коммуникативной инициативы и ее места в межличностном общении; 2) изучение влияния объективных факторов на частотность и форму проявления инициативы в процессе коммуникации; 3) анализ языковых средств, используемых при взятии и сохранении коммуникативной инициативы; 4) выделение основных стратегий, реализуемых инициатором общения; 5) определение значимости и условий влияния коммуникативной инициативы на характер и тональность общения (с. 52). Нельзя не согласиться с О.В. Лунёвой, доказывающей, что инициатива в общении является составной частью коммуникативного лидерства; в отличие от лидерства и активности, она всегда ситуативна, адресно направлена, предполагает обратную связь, переходность и выражение в вербальной форме (с. 58-59). Механизм коммуникативной инициативы, как установлено в исследовании, включает ряд константных и переменных составляющих. К первым относятся зарождение интенции, формулировка содержания сообщения на уровне внутренней речи, передача сигналов инициации общения, введение новой темы, мена коммуникативных ролей, передача сигналов завершения общения, ко вторым - гладкая мена коммуникативных ролей либо взятие инициативы силой, ее добровольная либо вынужденная передача партнеру по общению; развитие/смена темы говорящим либо собеседником и т.д. В книге показаны структурные единицы коммуникативной инициативы, ее стратегии и тактики.

М.А. Гуляева излагает результаты изучения вовлеченности в коммуникацию, описывает конститутивные признаки этого явления на когнитивном и поведенческом уровнях (восприимчивость, внимание и реагирование готовность к коммуникации, экспрессивность, управление интеракцией, альтероцентризм, отсутствие социального беспокойства) (с. 112). Вовлеченность в общение противопоставлена отчужденности. Автор справедливо отмечает, что в лингвистике еще недостаточно освещены характеристики 
вовлеченности в коммуникацию и предлагает рассматривать эту категорию как градуальное образование, включающее следующие позиции на условной шкале: сверхвовлеченность - высокая степень вовлеченности - низкая степень вовлеченности - отказ от общения (с. 113). Отмечено, что сверхвовлеченность в коммуникацию не способствует ее успешному осуществлению. Примером может служить чрезмерная родительская опека. Добавим к этому, что в культурах состязательного типа наблюдается резко отрицательное отношение к любым проявлениям патернализма. Этот тип вовлеченности проявляется, как показано в работе, в озабоченности собой и другими, характеризуется акцентированным вниманием к процессу общения и часто свидетельствует о повышенной тревожности такого коммуникативного субъекта. Высокая степень коммуникативной вовлеченности проявляется в естественном спонтанном общении. В исследовании подчеркивается значимость невербальных средств коммуникации как сигналов вовлеченности в общение. Коммуникативная отчужденность выражается в невнимании к партнеру по общению, инертности и направленности на завершение разговора. Крайней степенью отчужденности является отказ от общения. В работе показаны характеристики такого отказа. Эти наблюдения будут весьма интересны для исследователей в области конфликтологии и конфликтных языковых личностей.

М.С. Соколова анализирует типы и характеристики адаптации к собеседнику и коммуникативно релевантные способы социальной поддержки. Коммуникативная адаптация определяется как «процесс коммуникативного приспособления, актуализируемый на основании контекстуальных условий общения, статусно-ролевых и ситуативно-коммуникативных позиций его участников и проявляющийся в вариативности поведения личности для достижения коммуникативной цели» (с. 156). В книге справедливо отмечено, что такая адаптация является дискурсивно специфической, обнаруживая своеобразие в политической, рекламной, медийной и других сферах общения. Заслуживают внимания выделенные в исследовании отличия адаптации от других форм приспособления - псевдоадаптации, аккомодации, мимикрии, ассимиляции и конформизма (с. 164).

Интересна предложенная автором модель коммуникативной адаптации, включающая три группы детерминант - адресной, ситуативной и субъектной ориентации. К параметрам адресной ориентации относятся возрастная, гендерная, социальная и национально-культурная принадлежность адресата. Ситуативная ориентация определяется контекстуальными условиями взаимодействия - сферой, формой общения, наличием/отсутствием физических помех, типом взаимоотношений между собеседниками. Субъектная ориентация отражает индивидуально-личностную сферу адресанта (с. 183). Предложенная модель является развитием исследовательских конструктов, успешно применяемых для изучения субъектных и ситуативных характеристик общения. Заслуживают внимания выделенные в работе критерии успешной 
межличностной адаптации, к которым М.С. Соколова относит: 1) установление оптимального типа взаимоотношений с собеседником; 2) компенсацию существующих между коммуникантами культурных, языковых, возрастных и прочих различий; 3) уместный выбор вербальных и невербальных средств общения в рамках конкретной ситуации; 4) умение преодолевать коммуникативные барьеры различной природы; 5) формирование интерактивного смысла; 6) реализацию личной или социально-значимой интенции общения; 7) чувство внутреннего комфорта (с. 206).

Отмечу, что аргументы и выводы авторов подтверждаются интересными иллюстративными примерами, интерпретация которых не вызывает возражений. Подводя итоги выполненному исследованию, авторы справедливо отмечают, что «детальное рассмотрение позитивной коммуникации в различных типах дискурсов - межличностном, массмедийном, политическом, педагогическом и т. д. - может внести посильный вклад в разработку этических и аксиологических аспектов коммуникации» (с. 247).

Нет сомнения в том, что рецензируемая книга станет существенной вехой в развитии коммуникативной лингвистики и будет стимулировать дальнейшие исследования в этой области филологического знания.

(C) Vladimir Karasik, 2020
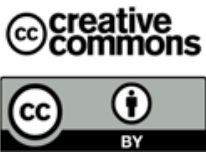

This work is licensed under a Creative Commons Attribution 4.0 International License https://creativecommons.org/licenses/by/4.0/

\section{СПИСОК ЛИТЕРАТУРЫ / REFERENCES}

Leontovich, Olga. 2019. "A Sensible Image of the Infinite": Intersemiotic Translation of Russian Classics for Foreign Audiences. Russian Journal of Linguistics, 23 (2). 399-414. Леонтович О.А. Введение в межкультурную коммуникацию. М.: Гнозис, 2007. 368 с. [Leontovich, Olga. 2007. Vvedenie v mezhkul'turnuju kommunikaciju (Introduction to Intercultural Communication). M.: Gnozis. 368].

Леонтович О.А. Методы коммуникативныхх исследований. М.: Гнозис, 2011. 224 с. [Leontovich, Olga. 2011. Metody kommunikativnyh issledovanij (Methods of Communication Studies). M.: Gnozis. 224].

Леонтович О.А. Русские и американиьы: парадоксы межкультурного общения. М.: Гнозис, 2005. 341 c. [Leontovich, Olga. 2005. Russkie i amerikancy: paradoksy mezhkul'turnogo obshhenija (Russian and Americans; Paradoxes of Intercultural Communication). M.: Gnozis. 341].

Леонтович О.А., Якушева Е.В. Понимание - начало согласия: межкультурная семейная коммуникация. М.: Гнозис, 2013. 224 с. [Leontovich Olga \& Elena Yakusheva. 2013. Ponimanie - nachalo soglasija: mezhkul'turnaja semejnaja kommunikacija (Understanding as the Beginning of Agreement; Intercultural Family Communication). M.: Gnozis. 224]. 


\section{Book review history:}

Received: 4 August 2020

Revised: 18 October 2020

Accepted: 21 October 2020

\section{История рецензии:}

Дата поступления в редакцию: 4 августа 2020

Дата принятия к печати: 21 октября 2020

Сведения об авторе:

Владимир Ильич КАРАСИК - доктор филологических наук, профессор кафедры общего и русского языкознания Государственного института русского языка имени А.С. Пушкина; профессор Тяньцзиньского университета иностранных языков (КНР). Специалист в области социолингвистики, прагмалингвистики, лингвокультурологии, теории дискурса.

\section{Контактная информация:}

Государственный институт русского языка имени А.С. Пушкина

Москва, 117485, ул. Академика Волгина, 6.

e-mail:vkarasik@yandex.ru

ORCID ID: 0000-0001-8306-5317

\section{Bionote:}

Vladimir KARASIK is Doctor of Philology (Advanced Doctorate), Professor at the Department of General and Russian Linguistics at Pushkin State Russian Language Institute (Moscow, Russia), and Professor at Tianjin Foreign Studies University (Tianjin, China). His research interests embrace sociolinguistics, cultural linguistics, pragmatics, and discourse analysis.

\section{Contact information:}

Pushkin State Russian Language Institute

Academic Volgin Str., 6, Moscow, 117485.

e-mail: vkarasik@yandex.ru

ORCID ID: 0000-0001-8306-5317 